\title{
Kemampuan Komunikasi Matematis Siswa SMP melalui Model Pembelajaran Kooperatif Tipe Match Mine
}

\author{
Erma Monariska ${ }^{1, *}$, Nia Jusniani ${ }^{2}$, Neng Hani Sapitri ${ }^{3}$ \\ ${ }^{1,2,3}$ Universitas Suryakancana \\ *ermamonariska@gmail.com
}

\begin{tabular}{|l|l|l|l|}
\hline Received: 08-02-2021 & Revised: 02-06-2021 & Accepted: 05-06-2021 & Published: 06-06-2021 \\
\hline
\end{tabular}

\begin{abstract}
ABSTRAK
Komunikasi matematis memiliki peranan penting karena dapat melatih siswa untuk meningkatkan kemampuan menyelesaikan masalah dengan berbagai bentuk antara lain merefleksikan gambar, tabel, grafik ke dalam ide-ide matematika, memberikan penjelasan ide, konsep atau situasi matematika dengan bahasa sendiri dalam bentuk penulisan secara matematis dan menyatakan peristiwa sehari-hari dalam bahasa atau simbol matematika. Penelitian ini bertujuan untuk mengetahui kemampuan komunikasi matematis siswa dengan menggunakan model pembelajaran kooperatif tipe Match Mine dan kemampuan komunikasi matematis siswa yang menggunakan model pembelajaran biasa, serta untuk mengetahui sikap siswa terhadap pembelajaran matematika dengan menggunakan model pembelajaran kooperatif tipe Match Mine. Penelitian dilakukan pada SMP Negeri 2 Warungkondang. Metode penelitiannya adalah metode eksperimen dengan jenis penelitiannya adalah Quasi Experiment. Desain penelitian berbentuk Two Group Randomized Posttest-Only Control Design. Setelah dilakukan tes awal (pretest) pada kedua kelas, selanjutnya dilaksanakan pembelajaran dengan perlakuan berbeda. Pada kelas eksperimen dilaksanakan pembelajaran dengan model kooperatif tipe Match Mine beserta pemberian lembar kerja siswa (LKS), sedangkan pada kelas kontrol hanya dilaksanakan pembelajaran biasa tanpa adanya LKS. Pokok bahasan yang disajikan dengan materi Statistika. Setelah proses pembelajaran selesai, selanjutnya dilakukan tes akhir (posttest). Berdasarkan analisis penelitian, diperoleh 1) Kemampuan komunikasi matematis siswa yang menggunakan model pembelajaran kooperatif tipe Match Mine lebih baik daripada kemampuan komunikasi matematis siswa yang menggunakan pembelajaran biasa; 2) Terdapat perbedaan peningkatan kemampuan komunikasi matematis siswa yang menggunakan model pembelajaran kooperatif tipe Match Mine dengan peningkatan kemampuan komunikasi matematis siswa yang menggunakan model pembelajaran biasa; dan 3) Sikap siswa terhadap pembelajaran matematika dengan menggunakan model pembelajaran kooperatif tipe Match Mine positif.
\end{abstract}

Kata Kunci: Pembelajaran Kooperatif Tipe Match Mine; Kemampuan Komunikasi Matematis.

\begin{abstract}
Mathematical communication has an important role because it can train students to improve problem solving skills in various forms, including reflecting pictures, tables, graphs into mathematical ideas, providing explanations of mathematical ideas, concepts or situations in their own language in the form of mathematical writing and stating everyday events in mathematical language or symbols. This study aims to determine students' mathematical communication skills using the Match Mine type cooperative learning model and students' mathematical communication skills using the ordinary learning model, as well as to determine students' attitudes towards learning mathematics using the Match Mine type cooperative learning model. The research was conducted at SMP Negeri 2 Warungkondang. The research method is an experimental method with the type of research being Quasi Experiment. The research design is in the form of Two Group
\end{abstract}


Randomized Posttest-Only Control Design. After the initial test (pretest) was carried out in both classes, then learning was carried out with different treatments. In the experimental class, learning is carried out using a Match Mine type cooperative model along with the provision of student worksheets (LKS), while in the control class only ordinary learning is carried out without LKS. The subject matter is presented with Statistics material. After the learning process is complete, then a final test (posttest) is carried out. Based on the research analysis, obtained 1) The mathematical communication ability of students who use the Match Mine type cooperative learning model is better than the mathematical communication skills of students who use ordinary learning; 2) There are differences in the improvement of students' mathematical communication skills using the Match Mine type cooperative learning model with the improvement of students' mathematical communication skills using the ordinary learning model; and 3) Students' attitudes towards learning mathematics by using a positive Match Mine type of cooperative learning model.

Keywords: Cooperative Learning Match Mine Type; Mathematical Communication Skills.

\section{PENDAHULUAN}

Sekolah adalah tempat seseorang atau suatu kelompok untuk membina ilmu pendidikan agar seseorang atau kelompok dapat mengembangkan dirinya menjadi lebih baik. Dalam pendidikan di sekolah terdapat beberapa mata pelajaran untuk diajarkan kepada seseorang atau kelompok yang sedang mencari ilmu, salah satunya adalah matematika. Mata pelajaran matematika dapat dijumpai di Sekolah Dasar (SD), Sekolah Menengah Pertama (SMP), Sekolah Menengah Atas (SMA)/Sekolah Menengah Kejuruan (SMK), sampai Sekolah Tinggi (ST)/ Universitas. Maka dari itu matematika menjadi salah satu pelajaran yang penting untuk diajarkan kepada seseorang atau suatu kelompok (Aunurrahman, 2011; Hikmawati, Nurcahyono, \& Balkist, 2019).

Kenyataan di lapangan pembelajaran matematika tidak menggunakan apersepsi untuk memancing motivasi siswa, metode ceramah yang berlangsung dari awal sampai akhir pembelajaran dengan siswa hanya mendengar penjelasan dari guru, tidak ada penguatan dari guru dan tidak ada siswa yang mengajukan pertanyaan apabila ada yang belum jelas dalam materi, serta tidak ada tindak lanjut sesuai evaluasi. Keadaan yang demikian mengakibatkan interaksi sosial dengan siswa lain tidak terjadi, metode yang demikian membuat kualitas pembelajaran yang kurang baik sehingga nilai hasil belajar yang dicapai siswa rendah, hal ini dapat dilihat dari hasil nilai rata-rata matematika yang tiap tahun menurun pada tingkat rendah (Iwan, 2011).

Komunikasi matematis merupakan salah satu kompetensi penting yang harus dikembangkan pada setiap topik matematika sebagaimana yang diungkapkan Guerreiro (2008), komunikasi matematis merupakan alat bantu dalam transmisi pengetahuan matematika atau sebagai dasar dalam membangun pengetahuan matematika. Komunikasi memungkinkan berpikir matematis dapat diamati dan karena itu komunikasi 
memfasilitasi pengembangan berpikir. Sejalan dengan itu, MES (2009), menyatakan bahwa komunikasi matematis merupakan salah satu komponen proses pemecahan masalah matematis. Komunikasi merupakan kemampuan untuk menggunakan bahasa matematika untuk mengekspresikan gagasan matematis dan argumen dengan tepat, singkat dan logis. Komunikasi membantu siswa mengembangkan pemahaman mereka terhadap matematika dan mempertajam berpikir matematis mereka. Lebih lanjut, Baroody (Hendriana, 2017) memperkuat bahwa komunikasi matematis digunakan dalam beragam konten matematika juga sebagai modal dalam menyelesaikan dan mengkonstruksi matematik serta sebagai sarana bertukar pendapat dan pikiran antar siswa.

Ketika para siswa berpikir, merespon, berdiskusi, menjelaskan, menulis, membaca, mendengarkan dan mengkaji tentang konsep-konsep matematika, mereka mendapatkan keuntungan ganda yaitu mereka berkomunikasi untuk mempelajari matematika, dan mereka belajar untuk berkomunikasi secara matematika. Ketika melakukan tugas matematika terdapat beberapa proses matematis, yaitu pemecahan masalah, representasi, refleksi, penalaran dan pembuktian, koneksi, pemilihan alat dan strategi, dan komunikasi (Yeager, A dan Yeager, R., 2008).

Kemampuan komunikasi matematis penting, namun kenyataannya kemampuan komunikasi matematis di Indonesia cenderung belum sesuai harapan. Rendahnya kemampuan komunikasi matematis dapat dilihat dari survei TIMSS (Trend In Mathematics and Science Study) dan PISA (Programme for International Student Assesment). Dalam survei TIMSS 2015 Indonesia menempati posisi 45 dari 50 negara. Survei tersebut dilaksanakan oleh IEA (International Energy Agency) setiap 4 (empat) tahun sekali. Hal ini sejalan dengan hasil penelitian munawaroh (2018) menunjukkan bahwa kemampuan komunikasi matematis siswa secara lisan maupun tertulis saat ini masih tergolong rendah.

Menurut data yang didapatkan dari Pusat Penilaian Pendidikan, Badan Penelitian dan Pengembangan (Puspendik Balitbang), Kementerian Pendidikan dan Kebudayaan mengenai hasil UN Matematika SMP 2016 mengalami penurunan terbesar pada pelaksanaan Ujian Nasional (UN) SMP/sederajat pada tahun 2016.

Rendahnya kemampuan komunikasi matematis siswa disebabkan oleh praktik pembelajaran yang kurang tepat. Guru cenderung lupa akan tujuan yang tercantum dalam kurikulum yang dibuat sebelumnya. Guru lebih terfokus pada materi yang harus selesai pada waktu yang ditentukan daripada harus membuat siswanya mampu dan dapat mengikuti pembelajaran dengan baik dengan cara menggunakan model pembelajaran yang 
lebih baik. Lebih lanjut Ansari (2012) mengungkapkan bahwa berbagai hasil penelitian menunjukkan bahwa merosotnya pemahaman matematik siswa di kelas antara lain karena: (1) dalam mengajar guru mencontohkan pada siswa bagaimana menyelesaikan soal; (2) siswa belajar dengan cara mendengar dan menonton guru melakukan matematik, kemudian guru memecahkannya sendiri; dan (3) pada saat mengajar matematika, guru langsung menjelaskan topik yang akan dipelajari, dilanjutkan dengan pemberian contoh dan soal untuk latihan. Kondisi pembelajaran yang disebutkan di atas juga berakibat tidak berkembangnya kemampuan komunikasi matematis siswa.

Oleh karena itu harus ada tindakan untuk memotivasi siswa agar lebih semangat belajar melalui perbaikan guru dalam memilih metode pengajaran. Metode pengajaran yang dipilih harus memberikan kesempatan kepada siswa untuk bertanya, bekerja sama antar siswa, membentuk hubungan positif, mengembangkan rasa percaya diri, serta meningkatkan kemampuan akademik secara kelompok. Sehingga konsep yang diajarkan oleh guru akan mudah ditangkap dan dipahami oleh siswa sehingga tercapainya kualitas pembelajaran yang lebih baik. Melalui pembelajaran ini siswa akan selalu mengingat tentang materi yang diajarkan.

Dalam proses belajar di kelas, seringkali masih ada siswa yang malu untuk bertanya kepada gurunya karena banyak hal. Karena tidak mampu untuk mengeluarkan pendapat tersebut, tidak menutup kemungkinan menjadikan siswa tidak dapat berkomunikasi dengan baik. Sebab pembelajaran di dalam kelas masih didominasi oleh guru atau teacher centre atau pembelajaran masih berpusat pada guru. Matematika umumnya identik dengan perhitungan angka-angka dan rumus-rumus, sehingga muncullah anggapan bahwa kemampuan komunikasi tidak dapat dibangun pada pembelajaran matematika. Anggapan ini tentu saja tidak tepat, karena menurut Greenes dan Schulman (1996), komunikasi matematis mempunyai peran :

1. Kekuatan sentral bagi siswa dalam merumuskan konsep dan strategi matematika;

2. Modal keberhasilan bagi siswa terhadap pendekatan dan penyelesaian dalam eksplorasi dan investigasi matematika;

3. Wadah bagi siswa berkomunikasi dengan temannya untuk memperoleh informasi, membagi pikiran dan penemuan, curah pendapat, menilai dan mempertajam ide untuk meyakinkan yang lain.

Berdasarkan uraian diatas, perlu dikembangkan suatu model pembelajaran yang erat kaitannya dengan kemampuan komunikasi matematis. Salah satunya adalah model pembelajaran kooperatif tipe Match Mine. Model pembelajaran kooperatif tipe Match Mine 
ini merupakan salah satu tipe pembelajaran yang dicetuskan oleh pakar pendidikan Spencer Kagan. Ia menyatakan dalam artikelnya yang berjudul "The Structucal Approach to Cooperative Learning" bahwa model pembelajaran kooperatif tipe Match Mine ini merupakan pembelajaran yang dapat membangun komunikasi (communication building) (Latifah, 2011; Kagan, 1989).

Penerapan Match Mine yang pertama adalah Draw What I Say. Dalam Glossary of Instructional Strategies menjelaskan bahwa aktifitas dari tipe pembelajaran Match Mine ini yang pertama adalah "Pair activity in which one student draws, while the other waits, then the second student tries to copy the drawing of the first using only descriptions supplied by the first student". Dalam proses ini, siswa pertama terlebih dahulu menggambarkan ide atau gagasannya. Kemudian siswa menyampaikan atau merefleksikan gambar (ide) secara lisan tersebut sehingga siswa kedua dapat membuat suatu gambar yang sama atau memiliki satu gagasan yang sama dengan teman pertama. Setelah selesai, keduanya mendiskusikan hasilnya. Penerapan Match Mine yang kedua adalah Build What I Write. Di dalam proses ini siswa memberikan ide-idenya secara tertulis. Ide-ide tersebut berupa gambar, grafik, tabel, permasalahan matematika dalam kehidupan sehari-hari dan sebagainya. Kemudian, siswa kedua membangun ide yang diberikan oleh temannya, lalu menjelaskan secara rinci maksud dari ide yang diberikan temannya. Setelah selesai, keduanya berdiskusi untuk menyamakan ide yang dimaksud tersebut. Model pembelajaran kooperatif tipe Match Mine memberikan banyak kesempatan kepada siswa untuk berinteraksi menyampaikan ideidenya, merefleksikan gagasan yang diberikan temannya dan berdiskusi menyamakan ide dengan temannya. Dari beberapa pernyataan yang telah diuraikan di atas, menunjukkan bahwa model pembelajaran kooperatif tipe Match Mine merupakan model pembelajaran yang menuntut siswa untuk memiliki kemampuan komunikasi matematis. Berdasarkan permasalahan di atas, maka peneliti tertarik untuk melakukan Penelitian dengan judul "Kemampuan Komunikasi Matematis Siswa SMP Melalui Model Pembelajaran Kooperatif Tipe Match Mine”.

Berdasarkan latar belakang yang telah di jelaskan sebelumnya, maka rumusan masalah penelitian ini adalah untuk mengetahui :

1. Apakah kemampuan komunikasi matematis siswa dengan menggunakan model pembelajaran kooperatif tipe Match Mine lebih baik daripada kemampuan komunikasi matematis siswa yang menggunakan model pembelajaran biasa?

2. Apakah terdapat perbedaan peningkatan kemampuan komunikasi matematis siswa yang menggunakan model pembelajaran kooperatif tipe Match Mine dengan 
peningkatan kemampuan komunikasi matematis siswa yang menggunakan model pembelajaran biasa?

3. Bagaimana sikap siswa dalam pembelajaran matematika dengan menggunakan model pembelajaran kooperatif tipe Match Mine?

\section{METODE PENELITIAN}

Metode penelitian yang dilakukan dalam penelitian ini adalah metode kuasi eksperimen pada dua kelas dengan perlakuan yang berbeda. Pada kelas eksperimen menggunakan model pembelajaran kooperatif tipe Match Mine, sedangkan pada kelas kontrol menggunakan pembelajaran biasa. Semua kelompok diberi tes awal (pretest) dan tes akhir (posttest). Instrumen yang digunakan berupa tes kemampuan komunikasi matematis dan angket skala sikap siswa. Tes kemampuan komunikasi matematis diberikan pada kedua kelas (sebelum dan setelah pembelajaran) sementara angket diberikan pada kelas eksperimen setelah selesai pembelajaran.

Teknik pengambilan sampel pada populasi terjangkau dalam penelitian ini menggunakan metode Cluster Random Sampling yaitu pengambilan sampel dengan cara mengambil 2 unit kelas untuk eksperimen dan kontrol. Dari populasi terpilih dua kelas yang menjadi sampel dalam penelitian ini, yaitu kelas VIII-C sebagai kelas eksperimen dan kelas VIII-D sebagai kelas kontrol.

Uji yang digunakan untuk menguji hipotesis statistik dalam penelitian ini adalah uji t berdasarkan variabel $\mathrm{x}$ dan y yang diukur. Uji hipotesis dengan menggunakan uji $\mathrm{t}$ dilakukan pada taraf signifikan $\alpha=0,05$.

\section{HASIL DAN PEMBAHASAN}

\section{Hasil Penelitian}

Data yang diperoleh dari penelitian ini adalah data skor pretest, skor posttest, skor indeks gain dan hasil angket. Pengolahan data yang dilakukan menggunakan softwere SPSS 24 dalam pengujian hipotesis dan Microsoft Excel 2010 untuk mengubah data ordinal ke dalam data interval pada angket. Data tersebut diperoleh dari sampel yang terdiri dari 60 siswa dengan 31 siswa kelas ekperimen yang memperoleh model pembelajaran kooperatif tipe Match Mine dan 29 siswa kelas kontrol yang memperoleh model pembelajaran biasa. 


\section{1) Hasil Penelitian Kemampuan Komunikasi Matematis Siswa}

Tabel 1. Deskripsi Statistik Data Pretest

\begin{tabular}{ccccccc}
\hline Kelas & N & $\begin{array}{c}\text { Skor } \\
\text { Ideal }\end{array}$ & Mean & $\begin{array}{c}\text { Std. } \\
\text { Deviasi }\end{array}$ & $\begin{array}{c}\text { Skor } \\
\text { Minimum }\end{array}$ & $\begin{array}{c}\text { Skor } \\
\text { Maksimum }\end{array}$ \\
\hline Eksperimen & 31 & 100 & 27,45 & 3,82 & 21 & 33 \\
Kontrol & 29 & 100 & 27,48 & 3,45 & 21 & 33 \\
\hline
\end{tabular}

Berdasarkan Tabel 1 di atas, dapat dilihat bahwa rata-rata skor pretest kelas eksperimen adalah 27,45 dengan standar deviasi 3,82. Sedangkan untuk kelas kontrol diperoleh rata-rata 27,48 dengan standar deviasi 3,45. Nilai pretest terendah kelas eksperimen adalah 21 dan nilai tertingginya 33, sedangkan nilai pretest terendah kelas kontrol adalah 21 dan nilai tertingginya 33. Dari deskripsi data tersebut terlihat bahwa skor rata-rata kelas eksperimen lebih kecil daripada skor rata-rata kelas kontrol dengan selisih rata-rata 0,03 .

Berdasarkan hasil uji normalitas distribusi populasi diperoleh nilai signifikansi untuk kelas eksperimen sebesar 0,00. Karena nilai signifikansi kelas eksperimen dan kelas kontrol kurang dari 0,05 maka dapat disimpulkan bahwa sampel kelas eksperimen dan kelas kontrol tidak berdistribusi normal. Sehingga untuk selanjutnya dilakukan uji MannWhitney untuk mengetahui kedua kelas memiliki kemampuan awal komunikasi matematis yang setara atau berbeda.

Tabel 2. Hasil Uji Mann Whitney Data Pretest

\begin{tabular}{cc}
\hline \multicolumn{2}{c}{ Data Pretest } \\
\hline Asymp. Sig. (2-tailed) & Keterangan \\
\hline 0,938 & $\mathrm{H}_{0}$ diterima \\
\hline
\end{tabular}

Berdasarkan hasil uji Mann Whitney yang terdapat pada Tabel 2 diperoleh nilai signifikansi 0,938. Nilai tersebut lebih dari 0,05 sehingga $\mathrm{H}_{0}$ diterima. Dengan demikian dapat disimpulkan bahwa kemampuan awal komunikasi matematis siswa kelas eksperimen dan kelas kontrol sama atau setara. Oleh karena kemampuan awal kedua kelas setara maka penelitian dapat dilanjutkan dengan memberikan perlakuan yang berbeda.

Tabel 3. Deskripsi Statistik Data Posttest

\begin{tabular}{ccccccc}
\hline Kelas & N & $\begin{array}{c}\text { Skor } \\
\text { Ideal }\end{array}$ & Mean & $\begin{array}{c}\text { Std. } \\
\text { Deviasi }\end{array}$ & $\begin{array}{c}\text { Skor } \\
\text { Minimum }\end{array}$ & $\begin{array}{c}\text { Skor } \\
\text { Maksimum }\end{array}$ \\
\hline Eksperimen & 31 & 100 & 87,52 & 7,62 & 75 & 100 \\
Kontrol & 29 & 100 & 71,41 & 18,28 & 25 & 96 \\
\hline
\end{tabular}


Berdasarkan Tabel 3 di atas, dapat dilihat bahwa rata-rata skor posttest kelas eksperimen adalah 87,52 dengan standar deviasi 7,62. Sedangkan untuk kelas kontrol diperoleh rata-rata 71,41 dengan standar deviasi 18,28. Nilai posttest terendah kelas eksperimen adalah 75 dan nilai tertingginya 100, sedangkan nilai posttest terendah kelas kontrol adalah 25 dan nilai tertingginya 96. Dari deskripsi data tersebut terlihat bahwa skor rata-rata kelas eksperimen lebih besar daripada skor rata-rata kelas kontrol dengan selisih rata-rata 16,11 .

Berdasarkan hasil uji normalitas distribusi populasi diperoleh nilai signifikansi untuk kelas eksperimen sebesar 0,00. Karena nilai signifikansi kelas eksperimen dan kelas kontrol kurang dari 0,05 maka dapat disimpulkan bahwa sampel kelas eksperimen dan kelas kontrol tidak berdistribusi normal. Sehingga untuk selanjutnya dilakukan uji MannWhitney untuk mengetahui apakah kedua kelas memiliki kemampuan akhir komunikasi matematis yang sama atau berbeda.

Tabel 4. Hasil Uji Mann Whitney Data Posttest

\begin{tabular}{cc}
\hline \multicolumn{2}{c}{ Data Posttest } \\
\hline Asymp. Sig. (2-tailed) & Keterangan \\
\hline 0,00 & $\mathrm{H}_{0}$ ditolak \\
\hline
\end{tabular}

Berdasarkan hasil uji Mann Whitney yang terdapat pada Tabel 4 diperoleh nilai signifikansi 0,00 . Nilai tersebut kurang dari 0,05 sehingga $\mathrm{H}_{0}$ ditolak. Dengan demikian dapat disimpulkan bahwa kemampuan akhir komunikasi matematis siswa kelas eksperimen dan kelas kontrol berbeda.

Tabel 5. Deskripsi Statistik Data Indeks Gain

\begin{tabular}{ccccccc}
\hline Kelas & N & $\begin{array}{c}\text { Skor } \\
\text { Ideal }\end{array}$ & Mean & $\begin{array}{c}\text { Std. } \\
\text { Deviasi }\end{array}$ & $\begin{array}{c}\text { Skor } \\
\text { Minimum }\end{array}$ & $\begin{array}{c}\text { Skor } \\
\text { Maksimum }\end{array}$ \\
\hline Eksperimen & 31 & 1,00 & 0,83 & 0,10 & 1,00 & 0,67 \\
Kontrol & 29 & 1,00 & 0,61 & 0,23 & 0,94 & 0,05 \\
\hline
\end{tabular}

Berdasarkan Tabel 5, dapat dilihat bahwa rata-rata indeks gain kelas eksperimen maupun kelas kontrol berbeda satu sama lain. Adapun berdasarkan Tabel tersebut rata-rata nilai indeks gain kelas eksperimen adalah 0,83 dan kelas kontrol adalah 0,61 dengan selisih rata-rata 0,22 . Angka tersebut memperlihatkan perbedaan rata-rata perolehan nilai indeks gain yang cukup besar antara kelas eksperimen dan kontrol, di mana nilai rata-rata indeks gain kelas eksperimen lebih baik daripada nilai rata-rata indeks gain kelas kontrol.

Berdasarkan hasil uji normalitas distribusi populasi diperoleh nilai signifikansi indeks gain untuk kelas eksperimen sebesar 0,001 dan kelas kontrol sebesar 0,006. Karena 
nilai signifikansi kelas eksperimen dan kelas kontrol kurang dari 0,05 maka dapat disimpulkan bahwa nilai indeks gain kelas eksperimen dan kelas kontrol tidak berdistribusi normal. Karena kelas eksperimen dan kelas kontrol berasal dari populasi yang tidak berdistribusi normal, maka analisis data dilanjutkan dengan uji statistik nonparametrik yaitu Uji Mann-Whitney.

Tabel 6. Hasil Uji Mann Whitney Data Posttest

\begin{tabular}{cc}
\hline \multicolumn{2}{c}{ Data Posttest } \\
\hline Asymp. Sig. (2-tailed) & Keterangan \\
\hline 0,00 & $\mathrm{H}_{0}$ ditolak \\
\hline
\end{tabular}

Berdasarkan hasil uji Mann Whitney yang terdapat pada Tabel 6 diperoleh nilai signifikansi 0,00 . Nilai tersebut kurang dari 0,05 sehingga $\mathrm{H}_{0}$ ditolak. Dengan demikian dapat disimpulkan bahwa terdapat perbedaan rata-rata nilai indeks gain yang signifikan antara kelas eksperimen dan kelas kontrol. Berdasarkan kesimpulan yang diperoleh dapat diketahui bahwa rata-rata nilai indeks gain kelas eksperimen lebih tinggi daripada rata-rata kelas kontrol. Dengan kata lain, peningkatan kemampuan komunikasi matematis kelas yang menggunakan model pembelajaran kooperatif tipe Match Mine (kelas eksperimen) lebih baik daripada kelas yang menggunakan model pembelajaran biasa (kelas kontrol). Hal ini sejalan dengan teori Spencer Kagan (Kagan,1989) yang mengatakan bahwa model pembelajaran kooperatif tipe Match Mine ini merupakan pembelajaran yang dapat membangun komunikasi. Hal itu dikarenakan pembelajaran kooperatif tipe match mine ini memungkinkan siswa untuk: 1) Mengorganisasi dan mengembangkan kemampuan berpikir matematis siswa melalui komunikasi; 2) Mengomunikasikan hasil pemikiran matematis siswa secara koheren dan jelas kepada rekan, guru dan lainnya; 3) Menganalisa dan menilai hasil pemikiran matematis dari orang lain; dan 4) Menggunakan bahasa matematika untuk mengekspresikan ide-ide matematis dengan tepat (Kagan, 2009). Hasil ini juga sesuai dengan penelitian Wahyuni dan Suwanto (2019) yang mengemukakan bahwa terdapat pengaruh positif model pembelajaran kooperatif tipe match mine terhadap kemampuan komunikasi matematik siswa.

\section{2) Hasil Angket Siswa}

Berikut adalah diagram hasil angket siswa. 


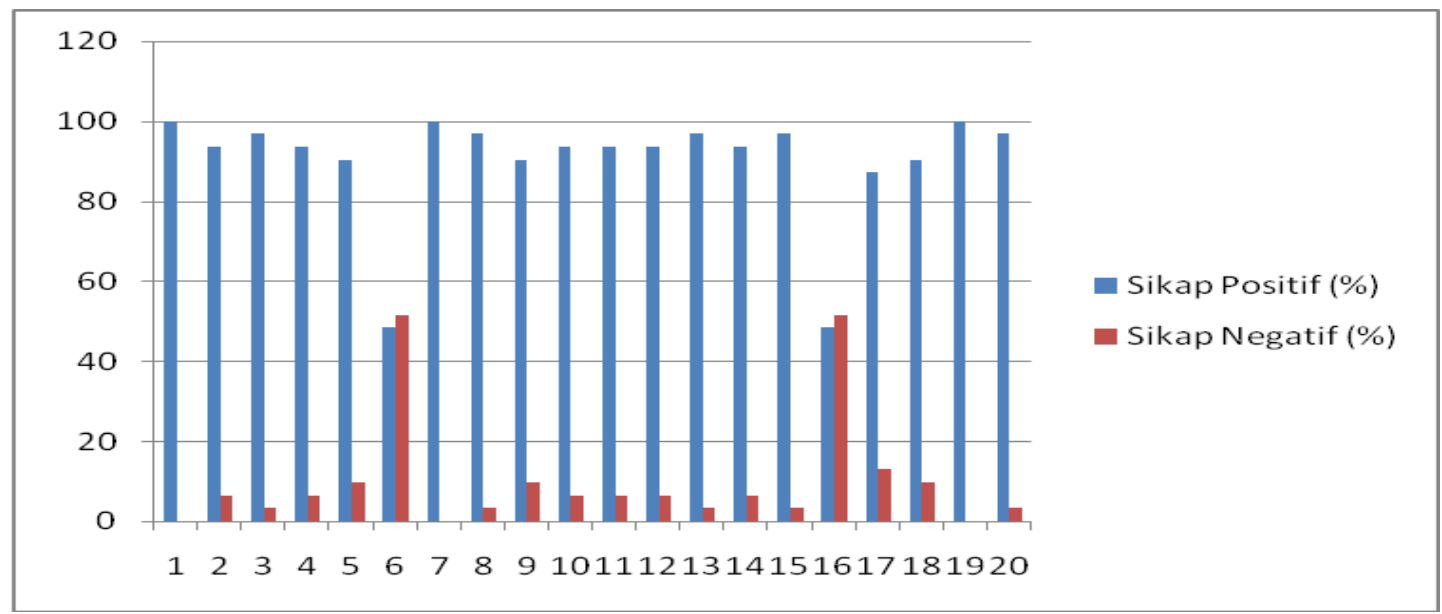

Gambar 1. Diagram Sikap Siswa

Berdasarkan Gambar 1 tersebut, diketahui bahwa hampir seluruh siswa memperoleh sikap positif pada setiap pernyataan. Sikap positif tersebut juga didasarkan hal yang menunjukkan bahwa siswa menerima dengan baik pembelajaran dengan model kooperatif tipe Match Mine. Hasil ini sejalan dengan hasil observasi terhadap kegiatan siswa selama pembelajaran kooperatif tipe Match Mine yang dilakukan Nasution dan Dewi (2015) yang menunjukkan adanya peningkatan rata-rata siswa dari berkategori cukup menjadi kategori baik. Sejalan dengan meningkatnya keaktifan siswa pada pembelajaran kooperatif tipe Match Mine membuat kemampuan komunikasi matematis siswa dan ketuntasan belajar siswa juga menagalami peningkatan. Hasil observasi itu menggambarkan adanya sikap positif siswa terhadap penerapan pembelajaran kooperatif tipe match mine.

\section{KESIMPULAN}

Kemampuan komunikasi matematis siswa yang menggunakan model pembelajaran kooperatif tipe Match Mine lebih baik daripada kemampuan komunikasi matematis siswa yang menggunakan pembelajaran biasa, terdapat perbedaan peningkatan kemampuan komunikasi matematis siswa yang menggunakan model pembelajaran kooperatif tipe Match Mine dengan siswa yang menggunakan model pembelajaran biasa, dan sikap siswa terhadap pembelajaran matematika dengan menggunakan model pembelajaran kooperatif tipe Match Mine positif.

\section{REFERENSI}

Ansari, B. I. (2012). Komunikasi Matematik dan Politik. Banda Aceh: Yayasan Pena. Aunurrahman. (2011). Belajar dan Pembelajaran. Bandung: Alfabeta.

Greens, C. dan Schulman, L. (1996). Communication Processes in Mathematics Education. Dalam Ellilot, P. C. dan Kanney, M. J. Communication in Mathematics, $K-12$ and Beyond. Virginia: NCTM. 
Guerreiro, Antonio. (2008). Communication in Mathematics Teaching and Learning Practices in Primary Education. [Online]. Tersedia: http://yess4.ktu.edu.tr/YermePappers/Ant \%20Guerreiro.pdf. [24 Desember 2018].

Hendriana, H. dkk. (2017). Hardskill dan Softskill Matematik Siswa. Bandung: PT. Refika Aditama.

Hikmawati, N.N., Nurcahyono, N.A., \& Balkist, P.J. (2019). Kemampuan Komunikasi Matematis Siswa dalam Menyelesaikan Soal Geometri Kubus dan Balok. Prisma : Jurnal Pendidikan Matematika, Volume VIII Nomor 1, halaman 68-79.

Iwan. (2011). Pengaruh Model Pembelajaran Kooperatif Tipe Match Mine Terhadap Kemampuan Komunikasi Matematik Siswa. Skripsi pada FKIP Universitas Suryakancana Cianjur: Tidak diterbitkan.

Kagan, S. (1989). The structural approach cooperative learning. San Clemente, CA: Kagan Publishing.

Kagan, M. (2009). Match mine mathematics. San Clemente, CA: Kagan Publishing.

Latifah. (2011). Pengaruh Model Pembelajaran Kooperatif Tipe Match Mine Terhadap Kemampuan Komunikasi Matematik Siswa. [Online] Tersedia: http://repository.uinjkt.ac.id/dspace/bitstream/123456789/183/1/101119-LATIFAHFITK.PDF [04 Juni 2018].

Ministry of Education Singapore (MES). (2009). The Singapore Model Method for Learning Mathematics. Singapore: EPB Pan Pacific.

Munawaroh, U. (2018). Kemampuan Komunikasi Matematis Siswa dan Faktor-faktor yang Mempengaruhinya. Skripsi Sarjana pada FKIP Universitas Muhammadiyah Ponorogo: diterbitkan.

Nasution, D. dan Dewi, I. (2015). Penerapan Model Pembelajaran Kooperatif Tipe Match Mine untuk Meningkatkan Kemampuan Komunikasi Matematis Siswa Kelas VII di MTs Negeri 2 Medan T.A. 2014/2015. Inspiratif. Vol. 1 No. 1, hal 96-111.

Wahyuni, F. dan Suwanto. (2019). Pengaruh Model Pembelajaran Kooperatif Tipe Match Mine Terhadap kemampuan Komunikasi Matematik Siswa. MES: Journal of Mathematics Education and Science . Uisu. Vol. 5, No. 1, hal. 59-63.

Yeager, A dan Yeager, R. (2008). Teaching Throught The Mathematical Processes. [Online]. Tersedia: gains-camppp.wikispaces.com [17 Maret 2019]. 